\title{
Bioactive peptides generated in an enzyme membrane reactor using Bacillus lentus alkaline peptidase
}

\author{
Thomas Eisele • Timo Stressler • Bertolt Kranz • \\ Lutz Fischer
}

Received: 27 September 2012/Revised: 28 November 2012/ Accepted: 11 December 2012/Published online: 11 January 2013

(C) The Author(s) 2013. This article is published with open access at Springerlink.com

\begin{abstract}
Bacillus lentus alkaline peptidase (BLAP) was used for casein $(\mathrm{CN})$ hydrolysis in an enzyme membrane reactor (EMR) because it was found that BLAP was competitively inhibited by its products. The employed membranes had different molecular weight cut-offs (MWCO 1, 5 and $10 \mathrm{kDa}$ ). It was shown that the productivity of the EMR could be significantly improved (28\%) in comparison with batch hydrolysis under the same conditions after $20 \mathrm{~h}$. All resulting EMR peptide mixtures showed a homogenous peptide pattern in HPLC-UV analysis. The obtained peptide mixtures exhibited Angiotensin-I-converting enzyme (ACE) inhibitory and antioxidative activity. The ACE inhibition of the peptide mixtures was dependent on the MWCO of the membranes. The resulting apparent $\mathrm{IC}_{50}$ values were 115,131 and $420 \mu \mathrm{g} \mathrm{ml}^{-1}$ for the 1,5 and $10 \mathrm{kDa}$ MWCO membranes, respectively. In kinetic studies, a mixed-type inhibition was observed for the three peptide mixtures. The radical scavenging activity was determined with the ABTS assay, and $\mathrm{IC}_{50}$ values between 20 and $25 \mu \mathrm{g} \mathrm{ml}^{-1}$ were obtained for the generated peptide mixtures. In addition, the identified VYPFPGPIPN peptide exhibited ACE inhibition and antioxidant activity with $\mathrm{IC}_{50}$ values of 325 and $6.2 \mu \mathrm{M}$, respectively. The peptide YQEPVLGPVRGPFPIIV exhibited radical scavenging activity with an $\mathrm{IC}_{50}$ value of $5.2 \mu \mathrm{M}$.
\end{abstract}

T. Eisele $\cdot$ T. Stressler $\cdot$ B. Kranz $\cdot$ L. Fischer $(\square)$ Department of Biotechnology, Institute of Food Science and Biotechnology, University of Hohenheim, Garbenstr. 25, 70599 Stuttgart, Germany

e-mail: lutz.fischer@uni-hohenheim.de
Keywords Bacillus lentus alkaline peptidase - Enzyme membrane reactor $\cdot$ ACE inhibition - Antioxidative peptides $\cdot$ Bioactive peptides

\section{Introduction}

Bacillus sp. are widely used for the production of several industrially utilised enzymes, such as amylases or peptidases [1]. The alkalophilic Bacillus lentus is one of these industrial organisms that produce a commercial peptidase preparation called 'BLAP' (Bacillus lentus alkaline peptidases) [2]. Today, one of the well-known applications of BLAP is in household detergents. Other applications should be sought, because a controlled and 'tailor-made' protein hydrolysis using affordable enzymes would also be of interest in food processing.

The enzymatic hydrolyses of proteins in batch processes have several disadvantages compared with hydrolyses in continuous systems, such as enzyme membrane reactors (EMRs). For example, the protein batch hydrolyses are more expensive because it is not possible to reuse the enzymes [3, 4]. Enzyme membrane reactor processes also have certain advantages due to the ease of immobilising the enzymes [5]. In such processes, peptidase activities can be exploited over a long reaction time, resulting in high productivity, continuous production of products of a consistent quality and permanent removal of the inhibiting peptide products [6-8]. An additional advantage for potential application in food processing is that enzyme inactivation is not required because this so-called 'processing aid' (enzyme) does not appear in the peptide mixtures (product) if the membranes are able to completely retain them.

Small peptides hydrolysed from milk and other protein sources have shown several bioactivities, such as inhibiting 
the Angiotensin-I-converting enzyme (ACE; EC 3.4.15.1) and lipoxygenase (LOX; EC 1.13.11.12) as well as antioxidative, antimicrobial and immunomodulatory properties [9-12]. Age-specific diseases have been related to oxidative stress [13], which might be reduced by antioxidants in food. The antioxidative properties of amino acids, peptides and proteins have been known for a long time [14-16]. In addition, the biofunctional and technofunctional properties of peptides are an interesting field of investigation. For example, lipid peroxidation causes deterioration in food quality, off-flavour, unacceptable taste and a shortened shelf life during storage.

The aim of our studies was to prepare consistent peptide mixtures by applying BLAP in an EMR using membranes with different molecular weight cut-offs (MWCOs). The assumed product inhibition that occurs frequently when working with BLAP should be prevented by use of the membranes. The standardised peptide mixtures were investigated for their ACE inhibitory activity and antioxidative capacity. To our knowledge, this is the first report of an investigation of BLAP in an EMR for this type of application.

\section{Materials and methods}

\section{Reagents}

Bacillus lentus alkaline peptidase (BLAP) was a kind gift from Biozym Scientific GmbH (Hessisch Oldendorf, Germany). Casein, hippuryl-L-histidyl-L-leucine (HHL) ( $\geq 98 \%$ ) and 2,2'azino-bis (3-ethylbenzothiazoline-6-sulphonic acid) diammonium salt (ABTS; $99 \%$ ) were obtained from Sigma-Aldrich (Schnelldorf, Germany). Peptide standards (95\% purity) were purchased from EMC (Tübingen, Germany). All other reagents used were of analytical grade.

\section{Casein hydrolyses}

\section{Enzyme membrane reactor (EMR)}

The EMR (Jülich Fine Chemicals, Jülich, Germany; Fig. 1) with a working volume of $10 \mathrm{ml}$ was used with a $0.5 \%$ (w/v) casein suspension at $\mathrm{pH} 8.0$ in $\mathrm{H}_{2} \mathrm{O}_{\mathrm{dd}}$, adjusted with $\mathrm{NaOH}(1 \mathrm{M})$. The EMR was operated at $40{ }^{\circ} \mathrm{C}$ to ensure a sufficient thermal stability of BLAP (unpublished data). Microbial growth was prevented by the addition of $\mathrm{NaN}_{3}$ $[0.05 \%(\mathrm{w} / \mathrm{v})]$ to the ice-cooled feed tank at the beginning of the process, after 8 and $16 \mathrm{~h}$. Transmembrane pressure was continuously monitored by a pressure gauge and did not exceed 2 bar. Casein hydrolysis was performed with BLAP (75 nkat casein $\mathrm{ml}^{-1}$; spec. EA: $100 \mathrm{nkat}_{\text {casein }} \mathrm{mg}^{-1}$ ). During the hydrolysis process, casein (substrate) was

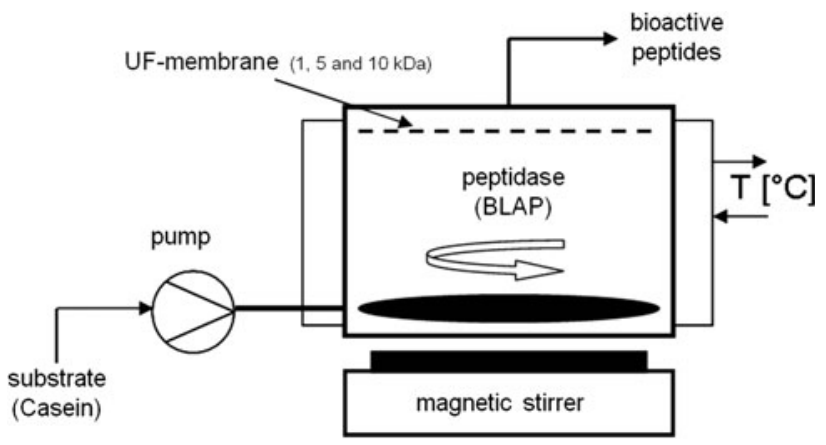

Fig. 1 Design and flow chart of the enzyme membrane reactor used for production of biofunctional and technofunctional peptides

retained by membranes with different molecular weight cut-offs [1, 5 and $10 \mathrm{kDa}$; polyethersulphone membranes, (PES)]. The substrate and permeate flows were kept constant at $10 \mathrm{ml} \mathrm{h}^{-1}$, so that a residence time of $1 \mathrm{~h}$ was achieved. The permeate was automatically fractionated (frac-100, GE, München, Germany) over $20 \mathrm{~h}$. The productivity was calculated as $g_{\text {dry }}$ weight $l^{-1} \mathrm{~h}^{-1}$, with the freeze-dried (CHRIST, ALPHA 1-2; Osterode am Harz, Germany) fractions corrected by salt using a freeze-dried blank without substrate (casein).

\section{Batch hydrolyses}

The batch casein hydrolysis was performed with a $10 \%$ (w/v) casein suspension in $\mathrm{H}_{2} \mathrm{O}_{\mathrm{dd}}$ at $\mathrm{pH} 8.0$ adjusted with $\mathrm{NaOH}(1 \mathrm{M})$ at $40{ }^{\circ} \mathrm{C}$ for $20 \mathrm{~h}$. The hydrolysis was performed in a $10 \mathrm{ml}$ scale using BLAP $\left(75 \mathrm{nkat}_{\text {casein }} \mathrm{ml}^{-1}\right.$; spec. EA: $100 \mathrm{nkat}_{\text {casein }} \mathrm{mg}^{-1}$ ). Microbial growth was prevented by the addition of $\mathrm{NaN}_{3}[0.05 \%(\mathrm{w} / \mathrm{v})]$ at the beginning of the process, after 8 and $16 \mathrm{~h}$. After $20 \mathrm{~h}$, the hydrolyses were stopped by ultrafiltration $(10 \mathrm{kDa}$; Vivaspin 500, Sartorius, Göttingen, Germany). The permeate was freeze dried. The productivity was calculated as $g_{\text {dry }}$ weight $1^{-1} \mathrm{~h}^{-1}$, with the freeze-dried fractions corrected by salt using a freeze-dried blank without substrate (casein).

Determination of proteolytic activity

The proteoloytic activity of BLAP was determined with a natural substrate and a chromogenic peptide.

\section{Determination of proteolytic activity with the ninhydrin} assay

Bacillus lentus alkaline peptidase activity was determined by a ninhydrin assay, which was performed according to the method of Reimerdes et al. [17] with minor modifications. Bovine casein $[0.5 \%(\mathrm{w} / \mathrm{v})]$ dissolved in $\mathrm{H}_{2} \mathrm{O}_{\mathrm{dd}}$ at pH 8.0 (adjusted with $1 \mathrm{M} \mathrm{NaOH}$ ) was used as the 
substrate. The substrate $(450 \mu \mathrm{l})$ was preincubated with $\mathrm{H}_{2} \mathrm{O}_{\mathrm{dd}}(225 \mu \mathrm{l})$ at $40{ }^{\circ} \mathrm{C}$ for $5 \mathrm{~min}$. Casein hydrolysis was initiated by the addition of the enzyme solution ( $225 \mu \mathrm{l}$, $\left.40{ }^{\circ} \mathrm{C}\right)$. The enzymatic hydrolysis was terminated after 1-20 min in intervals of $1 \mathrm{~min}$ using $0.35 \mathrm{M}$ TCA $(1,075 \mu \mathrm{l})$. To precipitate the unhydrolysed casein, the assay mixture was centrifuged $(13,000 \times g ; 5 \mathrm{~min})$. Afterwards, the resulting supernatant $(250 \mu \mathrm{l})$ was mixed with acetate buffer $(4 \mathrm{M}, \mathrm{pH} 5.5,250 \mu \mathrm{l}), \mathrm{NaOH}(1 \mathrm{M}, 75 \mu \mathrm{l})$ and ninhydrin reagent $(225 \mu \mathrm{l}, 1.74 \mathrm{~g}$ ninhydrin and $280 \mathrm{mg}$ hydrindantin dihydrate dissolved in $100 \mathrm{ml}$ methoxyethanol), incubated in a water bath $\left(95{ }^{\circ} \mathrm{C}\right.$ for $20 \mathrm{~min}$ ) and then placed on ice for $5 \mathrm{~min}$. Subsequently, the reaction mixture $(300 \mu \mathrm{l})$ was mixed with $50 \%(\mathrm{v} / \mathrm{v})$ isopropanol/water $(1,000 \mu \mathrm{l})$, and the absorbance was measured at $570 \mathrm{~nm}$ using a spectrophotometer (GE, München, Germany). The calibration curve was determined using tyrosine as a standard amino acid $(45-450 \mu \mathrm{M})$. One kat was defined as the release of $1 \mathrm{~mol}$ tyrosine equivalent per second.

\section{Determination of proteolytic activity with chromogenic substrate}

Bacillus lentus alkaline peptidase activity was analysed with SUC-Ala-Ala-Pro-Phe-pNA (Bachem, Bubendorf, Switzerland) as substrate. To determine BLAP activity, $227.5 \mu \mathrm{l}$ of the EMR permeate was used. The reaction mixture was preincubated at $40{ }^{\circ} \mathrm{C}$ for $10 \mathrm{~min}$. Afterwards, the chromogenic peptide $\left[12.5 \mu \mathrm{l}\right.$ of a $5 \mathrm{mg} \mathrm{ml}^{-1}$ solution, dissolved in dimethylformamide (DMF)] was added to start the reaction. The reaction was stopped by the addition of acetic acid $[50 \mu \mathrm{l} ; 50 \%(\mathrm{v} / \mathrm{v})]$. After centrifugation $(8,000 \times g, 5 \mathrm{~min}), 240 \mu \mathrm{l}$ of the solution was transferred to a microtiter plate, and the absorption was measured in an iEMS-Reader (Labsytems, Helsinki, Finland) at $405 \mathrm{~nm}$. One katal of proteolytic activity was defined as the amount of enzyme that released $1 \mathrm{~mol} p$-nitroaniline per second.

\section{Determination of product inhibition of BLAP} with azocasein assay

The azocasein assay was performed as described in [18] with minor modifications. Azocasein $\left(5 \mathrm{mg} \mathrm{ml}^{-1}\right)$ was dissolved in $\mathrm{H}_{2} \mathrm{O}_{\mathrm{dd}}$, and the $\mathrm{pH}$ was adjusted to $8.0(1 \mathrm{M}$ $\mathrm{NaOH})$. A $10 \mathrm{kDa}$ ultrafiltration permeate from a $2 \%$ (w/v) casein hydrolysis with $11 \mu \mathrm{kat}_{\text {casein }}$ BLAP in $\mathrm{H}_{2} \mathrm{O}_{\mathrm{dd}}$ at $\mathrm{pH} 8.0(10 \mathrm{~h}, 4.51 \mathrm{scale}$; adjusted with $1 \mathrm{M} \mathrm{NaOH})$ was used for BLAP inhibition studies. The casein hydrolysate was dissolved in each concentration of azocasein solution $\left(0.25-5 \mathrm{mg} \mathrm{ml}^{-1}\right)$. Azocasein inhibitor solution $(250 \mu \mathrm{l})$ was preincubated at $40{ }^{\circ} \mathrm{C}$ for $5 \mathrm{~min}$. The reaction was started by the addition of BLAP $\left(25 \mu \mathrm{l} ; 1.5 \mathrm{mg} \mathrm{ml}^{-1}\right.$ in
$\mathrm{H}_{2} \mathrm{O}, 0.45 \mu \mathrm{m}$ filtered). The reaction was terminated by TCA $(2 \mathrm{M}, 25 \mu \mathrm{l})$. Afterwards, the reaction mixture was centrifuged $(13,000 \times g, 5 \mathrm{~min})$. The resulting supernatant $(187 \mu \mathrm{l})$ was transferred to a microtiter plate and $\mathrm{NaOH}$ ( $1 \mathrm{M}, 62.5 \mu \mathrm{l})$ was added. The absorbance was measured at $450 \mathrm{~nm}$ in a microplate spectrophotometer (MULTISKAN FC, Thermo Scientific, Dreieich, Germany). One unit of enzyme activity was defined as the amount of enzyme which under the assay conditions described gives rise to an increase of one absorbancy at $450 \mathrm{~nm} \mathrm{~min}{ }^{-1}$.

Angiotensin-I-converting enzyme (ACE) inhibition assay

The ACE inhibition assay was performed according to a previously published method with some modifications [19]. Hippuryl-L-histidine-L-leucine (HHL, $5 \mathrm{mM}$ ) was dissolved in borate buffer $(0.1 \mathrm{M}$ containing $0.3 \mathrm{M} \mathrm{NaCl}, \mathrm{pH}$ 8.3) and used as the substrate. Porcine lung ACE $\left(\sim 37 \mathrm{U} \mathrm{mg}^{-1}\right)$ was diluted in borate buffer $(0.1 \mathrm{M}$ containing $0.3 \mathrm{M} \mathrm{NaCl}, \mathrm{pH} 8.3$ ) to a final activity of 100 $\mathrm{U}^{-1}$. The substrate $(75 \mu \mathrm{l})$ and sample or buffer $(10 \mu \mathrm{l})$ were preincubated at $37{ }^{\circ} \mathrm{C}$ for $5 \mathrm{~min}$. The reaction was started by the addition of ACE $(5 \mu \mathrm{l})$ and stopped by the addition of $\mathrm{HCl}(1 \mathrm{M}, 20 \mu \mathrm{l})$ after $30 \mathrm{~min}$. The products hippuric acid (HA) and L-histidine-L-leucine (HL), which were released during hydrolysis, were separated by RPC18 HPLC (SpectraSYSTEMS ${ }^{\mathrm{TM}}$, Thermo Scientific ${ }^{\mathrm{TM}}$, Dreieich, Germany) and detected at $228 \mathrm{~nm}$. Solvent A consisted of $0.1 \%(\mathrm{v} / \mathrm{v})$ formic acid (FA) in double-distilled water. Solvent B consisted of $0.1 \%(\mathrm{v} / \mathrm{v}) \mathrm{FA}$ in acetonitrile (ACN). The elution of HA and HL was performed with a gradient and a constant flow rate of $0.5 \mathrm{ml} \mathrm{min}^{-1}$. The conditions of the gradient elution were as follows: $0 \min$ (A: $100 \%$; B: $0 \%$ ), $20 \min$ (A: $50 \%$; B: $50 \%$ ), $22 \min (\mathrm{A}: 50 \%$; B: $50 \%$ ), $28 \min (\mathrm{A}: 100 \%$; B: $0 \%), 35$ min (A: $100 \%$; B: $0 \%$ ). A reversed phase $\mathrm{C} 18$ HPLC column (Aqua 5u $200 \AA$, $150 \mathrm{~mm} \times 4.6 \mathrm{~mm}$, $5 \mu \mathrm{M}$; Phenomenex, Germany) equipped with a GROMSIL 120 ODS-3 CP; $3 \mu \mathrm{M}(20 \mathrm{~mm} \times 4.6 \mathrm{~mm})$ precolumn was used. Usually, $10 \mu \mathrm{l}$ was injected in the HPLC. The $\mathrm{IC}_{50}$ was defined as the amount of hydrolysate or peptide required to reduce the area of the HA peak to $50 \%$.

ABTS antioxidation assay

The ABTS $\left[2,2^{\prime}\right.$-azino-bis (3-ethylbenzothiazoline-6-sulphonic acid) diammonium salt] antioxidation assay described in [20] was carried out with some modifications. The $\mathrm{ABTS}^{+}$stock solution was prepared with $\mathrm{ABTS}^{+}$ $(7 \mathrm{mM})$ and ammonium peroxodisulphate $(2.45 \mathrm{mM})$ in double-distilled water. Both were allowed to react for $12-16 \mathrm{~h}$ in the dark. $\mathrm{ABTS}^{+}$stock solution was used for 
no more than 2 days. The $\mathrm{ABTS}^{+}{ }^{+}$stock solution was diluted with phosphate-buffered saline (PBS; pH 7.4) to an absorption of $0.700 \pm 0.05$ at $734 \mathrm{~nm}$. The antioxidative activity was measured at $734 \mathrm{~nm}$ in a spectrophotometer. The sample $(10 \mu \mathrm{l})$ and diluted $\mathrm{ABTS}^{-+}$reagent $(1,000 \mu \mathrm{l})$ were mixed and incubated at $30{ }^{\circ} \mathrm{C}$ in the dark for $15 \mathrm{~min}$. The $\mathrm{IC}_{50}$ was defined as the amount of peptide mixture, standard peptide or trolox (dissolved in ethanol) required to reduce the absorbance of $\mathrm{ABTS}^{+}$to $50 \%$. The antioxidant capacity of the two standard peptides was expressed as trolox equivalent antioxidant capacity (TEAC). TEAC was calculated as the quotient of the slope of the standard peptide divided by the slope of trolox.

HPLC-UV analysis of the EMR peptide mixtures

Enzyme membrane reactor hydrolysates were analysed by HPLC using a SpectraSYSTEMS ${ }^{\mathrm{TM}}$ chromatograph (Thermo Scientific, Dreieich, Germany). The peptides were eluted with two solvents. Solvent A consisted of $0.1 \%$ (v/v) FA in $\mathrm{H}_{2} \mathrm{O}_{\mathrm{dd}}$, and solvent B consisted of $0.1 \%(\mathrm{v} / \mathrm{v}) \mathrm{FA}$ in ACN. The conditions of the gradient were as follows: $0-5 \min (\mathrm{A}$ : $100 \%$; B: $0 \%$ ), 5-45 min (A: $40 \%$; B: $60 \%$ ), 45-55 min (A: $40 \%$; B: $60 \%$ ), 55-57 min (A: $100 \%$; B: $0 \%$ ), 57-65 min (A: $100 \%$; B: $0 \%$ ). The HPLC column was a reversed phase $\mathrm{C} 18$ (Aqua $5 \mathrm{u}, 125 \mathrm{~A}, 250 \mathrm{~mm} \times 4.6 \mathrm{~mm}$, $5 \mu \mathrm{M}$; Phenomenex, Germany) equipped with a GROM-SIL 120 ODS-3 CP; $3 \mu \mathrm{M}(20 \mathrm{~mm} \times 4.6 \mathrm{~mm})$ precolumn. Usually, $20 \mu$ of the peptide mixture was injected. Separated peptides were eluted with a constant flow rate of $0.5 \mathrm{ml} \mathrm{min}^{-1}$ and detected at $220 \mathrm{~nm}$.

Mass spectrometric detection of peptides

Nano-LC-ESI-MS/MS experiments were performed on an ACQUITY nano-UPLC system (Waters, USA) coupled to an LTQ-Orbitrap XLhybrid mass spectrometer (Thermo Fisher Scientific, Germany). The sample was concentrated and desalted on a precolumn $(2 \mathrm{~cm} \times 180 \mu \mathrm{m}$, Symmetry C18, $5 \mu \mathrm{m}$ particle size, Waters, USA) and separated on a $20 \mathrm{~cm} \times 75 \mu \mathrm{m}$ BEH $130 \mathrm{C} 18$ reversed phase column $(1.7 \mu \mathrm{m}$ particle size, Waters, USA). A gradient elution was performed from 1 to $50 \% \mathrm{ACN}$ in $0.1 \%$ FA within $30 \mathrm{~min}$. The LTQ-Orbitrap was operated under the control of XCalibur 2.0.7 software.

\section{Results and discussion}

Product inhibition of Bacillus lentus alkaline peptidase

Product inhibition occurs during batch food protein hydrolyses [21, 22], leading to decreased productivity.
Therefore, BLAP was analysed for product inhibition using the azocasein assay (Fig. 2). This assay is based on the release of azo-derivatised casein peptides in the supernatant. Thus, non-derivatised peptides, which were generated by a prior BLAP casein hydrolysis, did not contribute to the absorbance measurement of the assay at $450 \mathrm{~nm}$.

As shown in the Lineweaver-Burk plot, BLAP was inhibited by its products (Fig. 2). The apparent $K_{m}$ values for the azocasein substrate clearly increased with higher peptide concentrations. The intercept in Fig. 2 was minimally shifted from the y-axis; however, theoretically, various types of inhibitory interactions between the complex peptide mixture and BLAP were possible. Nevertheless, the inhibition type appeared to be competitive inhibition. In addition, in prior work, an apparent uncompetitive product inhibition of $B$. subtilis peptidases (Alcalase) was described using the laborious trinitrobenzene sulphonic acid (TNBS) assay [23], which is inappropriate at high blank values in combination with a low degree of hydrolysis (DH). Generally, the TNBS method should be used with caution at very low DH [24]. Therefore, we recommend using the azocasein assay in endopeptidase inhibition studies due to its feasibility. The azocasein assay was also used by Fahmy et al. [25] in inhibitory studies of a cysteine peptidase from wheat using specific cysteine peptidase inhibitors. The product inhibition of BLAP should be avoided by using an EMR because the generated peptides are continuously removed from the hydrolysis vessel. As a result, higher productivities should be achieved in protein hydrolysis.

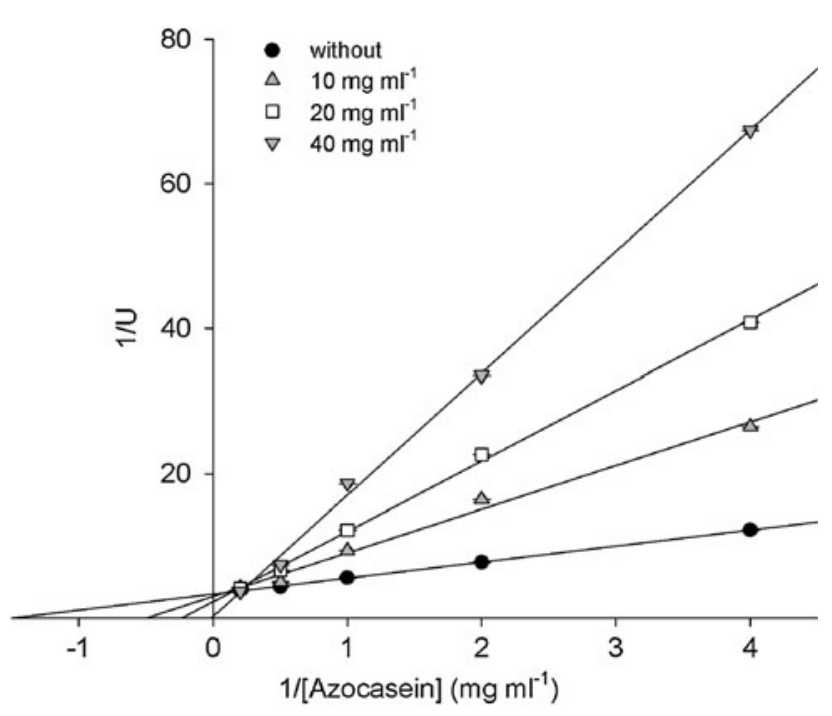

Fig. 2 Product inhibition of BLAP analysed by a Lineweaver-Burk plot using the azocasein assay $\left(450 \mathrm{~nm}, 40{ }^{\circ} \mathrm{C}, \mathrm{pH} 8.0\right)$ 
Fig. 3 Comparison of different HPLC-UV patterns of the resulting peptide mixtures in an EMR produced with 1 and $10 \mathrm{kDa}$ MWCO membranes

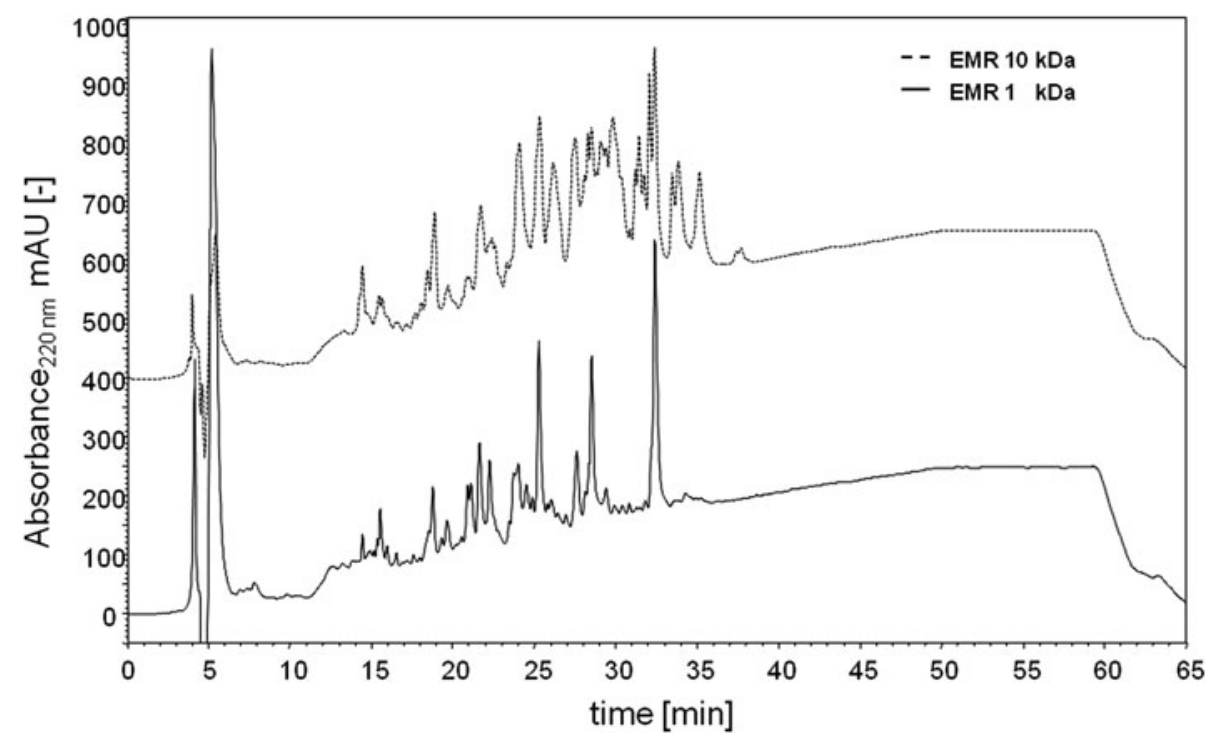

Hydrolysis of casein in an enzyme membrane reactor (EMR)

The desired retention of BLAP through three different UF membranes (1, 5 and $10 \mathrm{kDa}$ MWCOs) was checked in preliminary experiments (data not shown). In no case, BLAP activity could be detected in the permeates of the three MWCOs. The endopeptidases in BLAP did not pass through the membranes under the conditions used. Further investigations regarding the effect of the 1,5 and $10 \mathrm{kDa}$ membranes on the composition and bioactive properties of the resulting peptide mixtures were performed in a $10-\mathrm{ml}-$ scale EMR $\left(40{ }^{\circ} \mathrm{C}, 1 \mathrm{~h}\right.$ residence time, $0.5 \%$ casein feed, $75 \mathrm{nkat}_{\text {casein }} \mathrm{ml}^{-1}$ BLAP). First, the permeate samples containing the peptide mixtures were analysed by RP-C18 HPLC with UV detection. With each of the three membranes, the peptide patterns of the particular samples were consistent over the complete reaction time of $20 \mathrm{~h}$. Similar results were obtained by Lin et al. [6], who mentioned that peptide mixtures produced in EMR have a higher homogeneity compared with peptide mixtures produced in batch hydrolyses. Comparing the particular HPLC-UV patterns of the three different peptide mixtures obtained with the three membranes, significant differences were observed between the peptide mixtures of the 1 and the 5 or $10 \mathrm{kDa}$ MWCO membranes (Fig. 3). However, no significant differences in the HPLC-UV pattern of the peptides were observed between the 5 and $10 \mathrm{kDa}$ MWCO membrane (data not shown).

The corresponding calculated space-time yields of the EMR decreased from 3.2 to 2.9 to $1.0 \mathrm{~g} \mathrm{l}^{-1} \mathrm{~h}^{-1}$ for the 10 , 5 and $1 \mathrm{kDa}$ membranes, respectively (slopes in Fig. 4). Thus, feeding $5 \mathrm{~g} \mathrm{l}^{-1}$ of casein over the reaction time of $20 \mathrm{~h}\left(100 \mathrm{~g} \mathrm{l}^{-1}\right.$ substrate in total), a final yield of 64

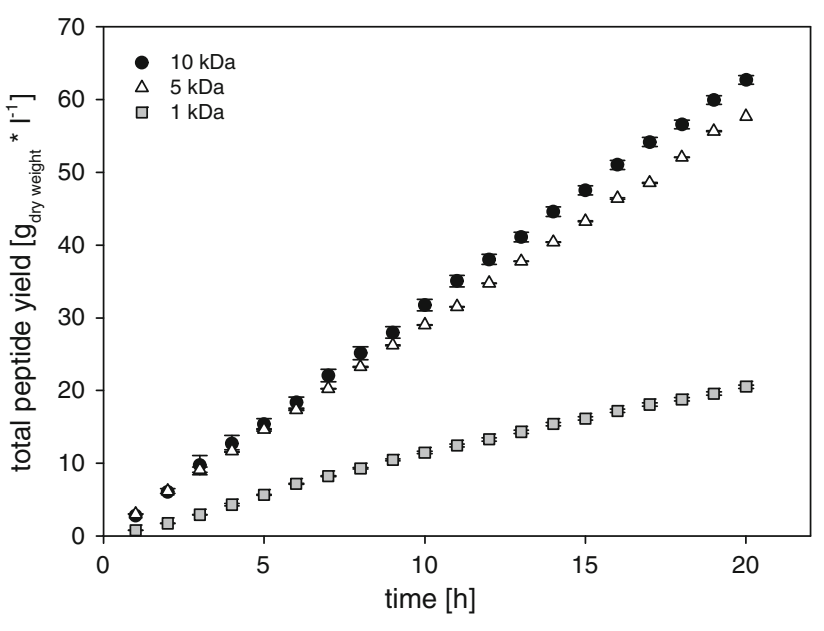

Fig. 4 Productivity of casein hydrolysis using membranes with different molecular weight cut-offs $(1,5$ and $10 \mathrm{kDa})$

(10 kDa), $58(5 \mathrm{kDa})$ and $20 \mathrm{~g} \mathrm{l}^{-1}(1 \mathrm{kDa})$ was recovered as dried peptide mixture.

When using a $10 \mathrm{kDa}$ membrane for peptide processing, the EMR reaction was compared with a batch reaction, applying the same total amounts of BLAP and substrate over $20 \mathrm{~h}$. The total peptide yield was $28 \%$ higher with the EMR $\left(64 \mathrm{~g} \mathrm{l}^{-1}\right)$ than the batch approach $\left(50 \mathrm{~g} \mathrm{l}^{-1}\right)$. We assume that both, the apparent prevention of product inhibition and the lower substrate concentration were responsible for the better performance of BLAP in the EMR.

Identification of generated peptides by nano-LC-ESI-MS/MS

The three different peptide mixtures were subjected to mass spectrometry to identify the generated peptide 
sequences. Peptide mixtures produced with 5 and $10 \mathrm{kDa}$ MWCOs each contained 128 peptides that were mostly similar but not identical. Fifty-one peptides were distinguished. As expected, the peptide mixture produced with $1 \mathrm{kDa}$ MWCO membrane contained considerably more peptides (221). For the penetration of the 1-kDa membrane, a higher degree of hydrolysis was necessary compared to the 5 and $10 \mathrm{kDa}$ MWCOs, and thus, the total number of peptides was increased. All identified peptide sequences were aligned with a database (BIOPEP database) and the literature (Scopus). The seven bioactive peptides identified are listed in Table 1.

Bioactive potential of the peptide mixtures

The three different peptide mixtures were lyophilised and examined for their bioactive potential, that is, their ACE inhibitory activity and antioxidative effects. Two of the most abundant peptides (VYPFPGPIPN and YQEPVLGPV RGPFPIIV) from the RP-C18-MS/MS analysis were chemically synthesised and separately evaluated for their bioactive potential.

\section{Antihypertensive effect and mechanism of ACE inhibition}

The ACE inhibitory effect of the three different peptide mixtures was investigated. The apparent $\mathrm{IC}_{50}$ values were determined for all peptide mixtures with a minimum of seven concentrations and were calculated to be 115,131 and $420 \mu \mathrm{g} \mathrm{ml}^{-1}$ for the 1,5 and $10 \mathrm{kDa}$ MWCO membranes, respectively. The apparent $\mathrm{IC}_{50}$ values of the 1 and $5 \mathrm{kDa}$ peptide mixtures were lower than that reported for fermented milk, which was $266 \mu \mathrm{g} \mathrm{ml}^{-1}$ [26]. The concentration-dependent ACE inhibition for the 5-kDa peptide mixture is shown in Fig. 5a. The type of ACE inhibition was analysed for the continuously produced peptide mixtures by linearisation after Lineweaver-Burk analysis (Fig. 5b). An apparent mixed-type inhibition of the ACE was observed in all three cases. The apparent $K_{i}$ values were calculated with 31,32 and $115 \mu \mathrm{g} \mathrm{ml}^{-1}$ for the 1 , 5 and $10 \mathrm{kDa}$ MWCO peptide mixtures, respectively. In comparison, the apparent $K_{i}$-value for captopril, a competitive pharmaceutical inhibitor for the treatment of hypertension, is reported to be $6.7 \mathrm{ng} \mathrm{ml}^{-1}$ [27]. However, the presence of peptides with different inhibition mechanisms was still possible due to the heterogeneity of the generated peptide mixtures. Typically, the mechanism of ACE inhibition is competitive [28]; however, uncompetitive, non-competitive, competitive as well as mixed inhibition mechanisms have been reported in the literature [27-29].

Furthermore, the two peptides V- $\beta$-casomorphin-9 (VYPFPGPIPN) and casecidin-17 (YQEPVLGPVRGPFPIIV) were assayed separately for ACE inhibitory activity. Casecidin-17 showed no ACE inhibitory activity at all in our trials. The $\mathrm{IC}_{50}$ of $\mathrm{V}$ - $\beta$-casomorphin- 9 against ACE was determined to be $325 \mu \mathrm{M}$. In the case of V- $\beta$-casomorphin-9, Saito et al. [30] previously published an $\mathrm{IC}_{50}$

Table 1 Known bioactive peptides identified in EMR peptide mixtures

\begin{tabular}{|c|c|c|c|c|c|c|c|}
\hline \multicolumn{4}{|c|}{ Current work } & \multicolumn{4}{|l|}{ Literature } \\
\hline $\begin{array}{l}\text { Observed } \\
\text { mass }\end{array}$ & $\begin{array}{l}\text { Calculated } \\
\text { mass }^{c}\end{array}$ & Sequence ${ }^{\mathrm{d}, \mathrm{e}}$ & $\begin{array}{l}\text { Peptide mixture by } \\
\text { MWCOs }[\mathrm{kDa}]\end{array}$ & Functional sequence $^{\mathrm{e}}$ & Function & $\begin{array}{l}\mathrm{IC}_{50} \\
{[\mu \mathrm{M}]}\end{array}$ & Reference \\
\hline $380.8966^{\mathrm{b}}$ & $1,139.6676$ & RPKHPIKHQ & 1 and 5 & RPKHPIKHQ & $\begin{array}{l}\text { ACE } \\
\text { inhibition }\end{array}$ & 13.4 & {$[30]$} \\
\hline $541.8143^{\mathrm{a}}$ & $1,081.6132$ & SQSKVLPVPQ & 1,5 and 10 & SQSKVLPVPQ & $\begin{array}{l}\mathrm{ACE} \\
\text { inhibition }\end{array}$ & 92.0 & {$[33]$} \\
\hline $443.8933^{\mathrm{b}}$ & $1,328.6560$ & ARHPHPHLSFM & 1,5 and 10 & ARHPHPHLSFM & antioxidative & n.d. & {$[34]$} \\
\hline $395.1773^{\mathrm{a}}$ & 788.3381 & AYFYPE & 1 & AYFYPEL & $\begin{array}{l}\text { ACE } \\
\text { inhibition }\end{array}$ & 6.58 & {$[35]$} \\
\hline $484.7494^{\mathrm{a}}$ & 967.4803 & GAWYYVPL & 1,5 and 10 & GAWYYVPL & $\begin{array}{l}\text { ACE } \\
\text { inhibition }\end{array}$ & $>1,000$ & {$[36]$} \\
\hline $550.7933^{\mathrm{a}}$ & $1,099.5702$ & VYPFPGPIPN & 1,5 and 10 & YPFPGPIPN & $\begin{array}{l}\mathrm{ACE} \\
\text { inhibition }\end{array}$ & 14.8 & {$[30]$} \\
\hline $941.0372^{\mathrm{a}}$ & $1,880.0560$ & YQEPVLGPVRGPFPIIV & 1,5 and 10 & YQEPVLGPVRGPFPIIV & antimicrobial & 266 & {$[37]$} \\
\hline \multicolumn{8}{|c|}{${ }^{\mathrm{a}}[\mathrm{M}+\mathrm{H}]^{++}$} \\
\hline \multicolumn{8}{|c|}{${ }^{b}[\mathrm{M}+\mathrm{H}]^{+++}$} \\
\hline \multicolumn{8}{|c|}{${ }^{\mathrm{c}}$ Calculated monoisotopic mass } \\
\hline \multicolumn{8}{|c|}{${ }^{\mathrm{d}}$ Protein sequence obtained with Mascot database } \\
\hline \multicolumn{8}{|c|}{ e Bold letters share no sequence homology } \\
\hline
\end{tabular}



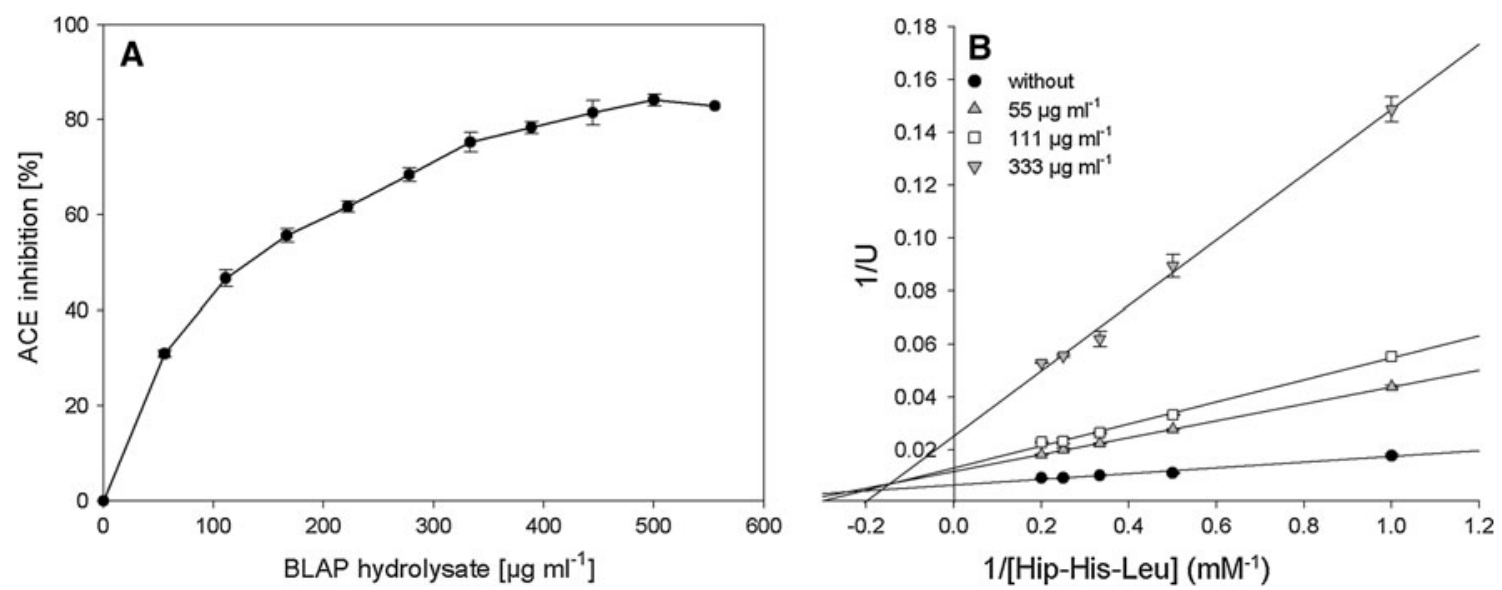

Fig. 5 ACE inhibition by the EMR 5 kDa peptide mixture (a) and Lineweaver-Burk plot of ACE inhibition in the presence of the BLAP 5 kDa MWCO peptide mixture (b)
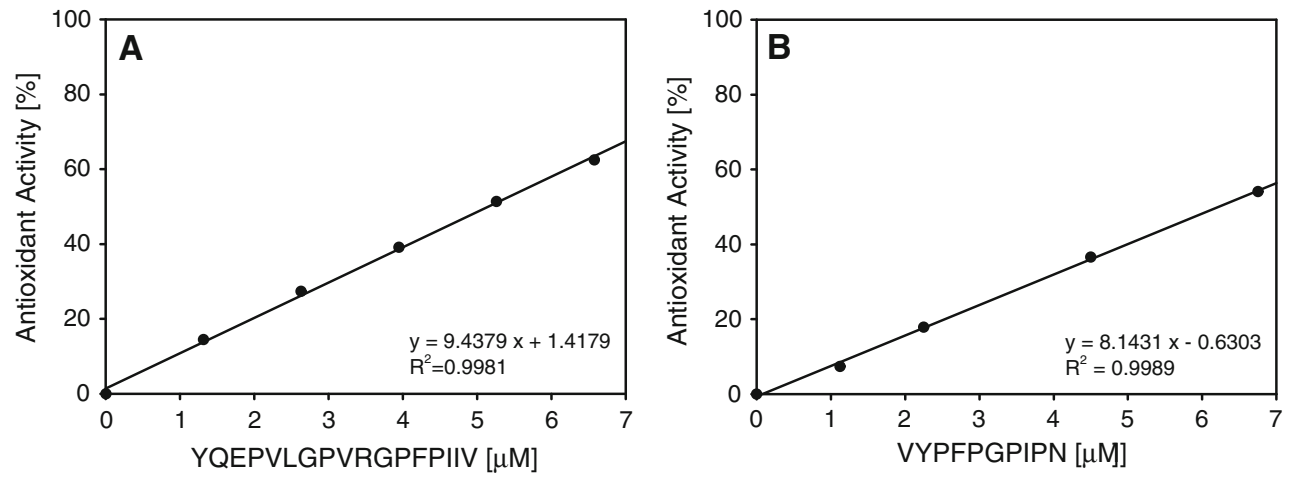

Fig. 6 Relationship between the concentration and antioxidant activity of casecidin-17 (a) and V- $\beta$-casomorphin-9 (b)

value of $14.8 \mu \mathrm{M}$ for $\beta$-casomorphin-9 (YPFPGPIPN), which exhibits a structural resemblance to V- $\beta$-casomorphin9 (VYPFPGPIPN). Therefore, we conclude that additional $\mathrm{Val}$ at the N-terminal end of $\mathrm{V}$ - $\beta$-casomorphin- 9 increased the $\mathrm{IC}_{50}$ value almost 22-fold from 14.8 to $325 \mu \mathrm{M}$.

\section{Antioxidative effects of the peptide mixtures}

The antioxidative effects of the three peptide mixtures and the two peptides V- $\beta$-casomorphin- 9 and casecidin- 17 were determined with the ABTS decolorisation assay. The antioxidant activities of the peptide mixtures were expressed as $\mathrm{IC}_{50}$ values in $\mu \mathrm{g} \mathrm{ml}^{-1}$ and compared with the standard trolox, a water-soluble vitamin $\mathrm{E}$ derivative. In our results, dose-dependent radical scavenging activity was observed.

The $\mathrm{IC}_{50}$ values were calculated to be 24,25 and $20 \mu \mathrm{g} \mathrm{ml}^{-1}$ for the peptide mixtures produced with the 1,5 and $10 \mathrm{kDa}$ MWCO membranes, respectively. The substrate $\mathrm{CN}\left(\mathrm{IC}_{50}=36 \mu \mathrm{g} \mathrm{ml}^{-1}\right)$ itself also showed radical scavenging activity. In comparison with the most effective peptide mixture obtained by the $10 \mathrm{kDa} \operatorname{EMR}\left(20 \mu \mathrm{g} \mathrm{ml}^{-1}\right)$,
$44 \%$ more antioxidant capacity was generated due to the hydrolysis of $\mathrm{CN}$.

Both peptides, casecidin-17 and V- $\beta$-casomorphin-9, showed a dose-dependent antioxidative effect [Fig. 6a, b]. Their $\mathrm{IC}_{50}$ values were 5.2 and $6.2 \mu \mathrm{M}$, respectively. Sadat et al. [31] also identified tyrosine-containing peptides from bovine $\alpha$-lactalbumin hydrolysis. The calculated $\mathrm{IC}_{50}$ values were $6.2,8.0$ and $0.5 \mu \mathrm{M}$ for the peptides YDTQA, INY and INYW, respectively. An antioxidative peptide with the sequence IVGGFPHYL was recently purified from sand eel Hypoptychus dybowskii by Lee et al. [32]. The purified peptide had a mass of 1,189 Da and an $\mathrm{EC}_{50}$ value of $22.75 \mu \mathrm{M}$ determined with the DPPH assay.

The resulting TEACs of the peptides were $1.95(\mathrm{~V}-\beta$ casomorphin-9) and 2.3 (casecidin-17), so both demonstrated a significantly higher antioxidant capacity than trolox.

\section{Conclusions}

Bacillus lentus alkaline peptidase was inhibited by its peptides produced during $\mathrm{CN}$ hydrolysis in a batch reactor. 
The product inhibition could be avoided by using an EMR. This strategy increased the productivity of the EMR (10 kDa MWCO membrane) up to $28 \%$ compared with the batch hydrolysis when equal total amounts of $\mathrm{CN}$ were used. Different peptide mixtures were continuously generated by BLAP in the EMR using different MWCOs $(1,5$ and $10 \mathrm{kDa}$ ). These peptide mixtures exhibited diverse ACE inhibitory and antioxidant activities. In kinetic studies, the peptide mixtures showed a mixed-type inhibition of ACE, and in addition, the apparent $\mathrm{IC}_{50}$ values were dependent on the employed MWCOs $(1<5<10 \mathrm{kDa})$. The $\mathrm{CN}$ hydrolysate produced by the $10 \mathrm{kDa}$ MWCO EMR showed the highest antioxidant activity of the three peptide mixtures. The peptide VYPFPGPIPN was identified as a strong antioxidative peptide and a weak ACE inhibitor, whereas the second verified peptide, YQEPVLGPVRGPFPIIV, showed no ACE inhibition but had strong antioxidant capacity.

Acknowledgments The authors would like to thank Dr. Jens Pfannstiel and Iris Klaiber for LC-ESI-MS/MS measurements. We would like to express our gratitude to the German Federal Ministry of Economics and Technology (AIF/FEI Project No. $16541 \mathrm{~N}$ ) for partial financial support of this research.

Open Access This article is distributed under the terms of the Creative Commons Attribution License which permits any use, distribution, and reproduction in any medium, provided the original author(s) and the source are credited.

\section{References}

1. De Boer AS, Priest F, Diderichsen B (1994) Appl Microbiol Biotechnol 40:595-598

2. Jørgensen PL, Tangney M, Pedersen PE, Hastrup S, Diderichsen B, Jørgensen ST (2000) Appl Environ Microbiol 66:825-827

3. Cheftel C, Ahern M, Wang DIC, Tannenbaum SR (1971) J Agric Food Chem 19:155-161

4. Guadix A, Camacho F, Guadix EM (2006) J Food Eng 72: 398-405

5. Trusek-Holownia A, Noworyta A (2008) Desalination 221: 543-551

6. Lin SB, Chiang WD, Cordle CT, Thomas RL (1997) J Food Sci 62:480-483

7. Wei JT, Chiang BH (2009) J Sci Food Agric 89:372-378
8. Cheison SC, Wang Z, Xu SY (2007) J Agric Food Chem 55: 3896-3904

9. Jäkälä P, Vapaatalo H (2010) Pharmaceuticals 3:251-272

10. Jung WK, Mendis E, Je JY, Park PY, Byeng WS, Hyoung CK, Yang KC, Kim SK (2006) Food Chem 94:26-32

11. Hsu KC (2010) Food Chem 122:42-48

12. Schurink M, van Berkel WJH, Wichers HJ, Boeriu CG (2007) Peptides 28:2268-2275

13. Pihlanto A (2006) Int Dairy J 16:1306-1314

14. Marcuse R (1960) Nature 186:886-887

15. Bishov SJ, Henick AS, Koch RB (1960) Food Res 25:174-182

16. Bishov SJ, Henick AS (1972) J Food Sci 37:873-875

17. Reimerdes EH, Klostermeyer H (1976) Method Enzymol 45:26-28

18. Leighton TJ, Doi RH, Warren RAJ, Kelln RA (1973) J Mol Biol 76:103-122

19. Cushman DW, Cheung HS (1971) Biochem Pharmacol 20: 1637-1648

20. Re R, Pellegrini N, Proteggente A, Pannala A, Yang M, RiceEvans C (1999) Free Radic Bio Med 26:1231-1237

21. Sousa R Jr, Lopes GP, Tardioli PW, Giordano RLC, Almeida PIF, Giordano RC (2004) Brazil J Chem Eng 21:147-153

22. Tardioli PW, Sousa R Jr, Giordano RC, Giordano RLC (2005) Enzyme Microb Technol 36:555-564

23. Demirhan E, Apar DK, Özbek B (2011) J Food Sci 76:C64-C67

24. Nielsen PM, Petersen D, Dambmann C (2001) J Food Sci 66:642-646

25. Fahmy AS, Ali AA, Mohamed SA (2004) Bioresour Technol 91:297-304

26. Tsai JS, Chen TJ, Pan BS, Gong SD, Chung MY (2008) Food Chem 106:552-558

27. Tsai JS, Chen JL, Pan BS (2008) Process Biochem 43:743-747

28. Mäkinen S, Johannson T, Vegarud Gerd E, Pihlava JM, Pihlanto A (2012) J Funct Foods 4:575-583

29. Pedroche J, Yust MM, Girón-Calle J, Alaiz M, Millán F, Vioque J (2002) J Sci Food Agric 82:960-965

30. Saito T, Nakamura T, Kitazawa H, Kawai Y, Itoh T (2000) J Dairy Sci 83:1434-1440

31. Sadat L, Cakir-Kiefer C, N'Negue MA, Gaillard JL, Girardet JM, Miclo L (2011) Int Dairy J 21:214-221

32. Lee WS, Jeon JK, Byun HG (2011) Process Biochem 46:12071211

33. Hayes M, Stanton C, Slattery H, O'Sullivan O, Hill C, Fitzgerald GF, Ross RP (2007) Appl Environ Microbiol 73:4658-4667

34. Kudoh Y, Matsuda S, Igoshi K, Oki T (2001) J Jpn Soc Food Sci 48:44-50

35. Contreras MdM, Carrón R, MdM Contreras, Montero MJ, Ramos M, Recio I (2009) Int Dairy J 19:566-573

36. Yamamoto N, Akino A, Takano T (1994) J Dairy Sci 77:917-922

37. Birkemo GA, O'Sullivan O, Ross RP, Hill C (2009) J Appl Microbiol 106:233-240 